\title{
Ultrastructure of Circulating Lymphocytes in Thymus Disorders
}

\author{
K. Willms-Kretsahmer, R. R. Kretsahmer, and F. S. Rosen ${ }^{[31]}$ \\ Universidad Nacional Autonoma de Mexico, Instituto Mexicano del Seguro Social, Mexico, D.F. Mexico, \\ and Harvard Medical School, and Children's Hospital Medical Center, Boston, Massachusetts, USA
}

\begin{abstract}
Extract
Peripheral blood lymphocytes of normal children, children with viral infections, and children with congenital thymic disorders were examined by electron microscopy. Lymphoid cells were classified as small or medium lymphocytes, lymphoblasts, plasmablasts, or plasma cells by certain morphological criteria. Enumeration and classification of cells in normal children revealed that $73.4 \%$ were small lymphocytes and $26.6 \%$ were medium lymphocytes. No lymphoblasts, plasmablasts, or plasma cells were found in peripheral blood of normal children. In children with infections or congenital thymic disorders, small but significant numbers of lymphoblasts, plasmablasts, and plasma cells were found. Medium lymphocytes were twice as numerous as small lymphocytes. In congenital thymic disorders, there was an absolute depletion of small lymphocytes, whereas medium lymphocytes and more immature forms were present in normal numbers in peripheral blood.
\end{abstract}

\section{Speculation}

The absence of thymus-dependent immunological function is correlated with a deficit in small lymphocytes. This may be due to an absence of the bone marrow precursors of these cells or to a lack of thymic influence on a cell type which remains unidentified.

\section{Introduction}

Thymus disorders (TD) constitute a heterogeneous group of immunodeficiencies with variable degrees of lymphopenia and defective cellular immunity. Some of these diseases evolve with abnormal humoral immunity and immunoglobulin defects; other TD are associated with normal antibody production and immunoglobulin levels [7, 12, 23].

The most severe type is combined immune deficiency (CID), of which an autosomal recessive and an X-linked recessive type have been described. In both, lymphopenia is usually severe, and cellular immunity, including the in vitro blastogenic response to mitogens, is absent; these patients also exhibit agammaglobulinemia $[10,14]$.
A second type is the recently described congenital hypoplasia of the thymus (CHT), or DiGeorge's syndrome, with moderate lymphopenia, defective cellular immunity, and a poor in vitro blastogenic transformation to specific and nonspecific stimuli. These patients have normal immunoglobulin levels, and their humoral antibody production appears adequate. Such children invariably have defective parathyroid function, the first clinical manifestation of the disease being neonatal tetany due to hypocalcemia. The signs and symptoms of this syndrome have been attributed to abnormal embryogenesis of the 3rd and 4th pharyngeal pouches $[6,15]$.

The most striking feature of TD is the absence of cellular immunity, a response which largely depends 
on the function of small lymphocytes [2]. It was thus of interest to compare the ultrastructure of Iymphocytes from patients with these diseases with ultrastructure of lymphocytes of immunocompetent children. Because of their accessibility, circulating blood lymphocytes were chosen for study with an awareness of the limitation such a choice implies, since the different compartments of the lymphoid system, thoracic duct, lymphätics, blood, lymphoid organs, bone marrow, etc., cannot be considered structurally or functionally homogeneous $[8,9,22]$.

\section{Materials and Methods}

\section{Thymus Disorders}

This group included four patients, two with severe combined immune deficiency of the X-linked and autosomal recessive types (these patients were 9 and 10 months of age at the time of study) and two cases of DiGeorge's syndrome (CHT) (both 18 months of age at the time of study). The immunological status of these patients is summarized in Table $\mathrm{I}$.

\section{Control Groups}

The first control group was comprised of four immunologically normal children, whose ages varied between 6 and 8 months, admitted for noninfectious problems to the Orthopedic or Ophthalmology Services at Children's Hospital Medical Center in Boston.

A second control group was comprised of six immunologically normal children, aged 6-21 months, admitted to the Pediatric Hospital, Centro Medico Nacional, I.M.S.S., in Mexico City for acute viral infections (Table II).

From each child, $10 \mathrm{ml}$ heparinized venous blood were obtained and centrifuged for $20 \mathrm{~min}$ at 1,500 rpm. The buffy coat and supernatant plasma were separated and recentrifuged to obtain a cell pellet which was fixed for $5 \mathrm{~min}$ in $2.5 \%$ phosphate-buffered glutaraldehyde ( $\mathrm{pH} 7.4$ ) and then trimmed to 1-mm blocks and fixed for another $60-90 \mathrm{~min}$. Tissues were postfixed in $1 \%$ osmium-tetroxide, dehydrated, and embedded in Epon-812. Ultrathin sections (600-1000 $\AA)$ were stained with uranylacetate and lead citrate, and examined in an electron microscope [28]. Lymphoid cells were photographed and classified according to characteristics shown in Table III. Cell morphology was evaluated according to recent electron microscopic studies of the lymphoid system [1, 3, 13, 17, 20, 27]. Examples of each cell type are shown in Figures 1-7. Cells were classified as blood monocytes when they
Table I. Immunological status of patients with thymus disorders

\begin{tabular}{|c|c|c|c|c|c|c|}
\hline Patient & Sex & Diagnosis $^{1}$ & $\begin{array}{c}\text { Blood, } \\
\text { lymphocytes } / \mathrm{mm}^{3}\end{array}$ & $\begin{array}{c}\text { Delayed } \\
\text { hyper- } \\
\text { sensi- } \\
\text { tivity, } \\
\text { skin } \\
\text { test }^{2}\end{array}$ & $\begin{array}{l}\text { Phyto- } \\
\text { hemagglu- } \\
\text { tinin } \\
\text { response } \\
\text { in vitro }\end{array}$ & $\begin{array}{l}\text { Develop- } \\
\text { ment of } \\
\text { paracortical } \\
\text { areas in } \\
\text { lymph } \\
\text { nodes }\end{array}$ \\
\hline$R R$ & $\mathrm{M}$ & CID & Low (900) & - & - & - \\
\hline$D C$ & $\mathrm{~F}$ & CID & Low (850) & - & - & - \\
\hline$E M$ & $\mathrm{M}$ & CHT & $\begin{array}{l}\text { Low normal } \\
\quad(1200)\end{array}$ & - & Poor & Poor \\
\hline$C P$ & $\mathrm{M}$ & CHT & $\begin{array}{l}\text { Normal } \\
\quad(2500)\end{array}$ & - & Poor & Poor \\
\hline Patient & Sex & Diagnosis & Immunoglobulins & $\begin{array}{c}\text { Hu- } \\
\text { moral } \\
\text { anti- } \\
\text { bodies }\end{array}$ & $\begin{array}{l}\text { Plasma } \\
\text { cells in } \\
\text { bone } \\
\text { marrow }\end{array}$ & $\begin{array}{l}\text { Develop- } \\
\text { ment of } \\
\text { germinal } \\
\text { centers in } \\
\text { lymph } \\
\text { nodes }\end{array}$ \\
\hline$R R$ & $M$ & GID & Less than $5 \%$ & - & - & - \\
\hline$D C$ & $\mathrm{~F}$ & CID & Less than $5 \%$ & - & - & - \\
\hline$E M$ & $\mathrm{M}$ & CHT & Normal & + & + & + \\
\hline$C P$ & $\mathrm{M}$ & CHT & Normal & + & + & + \\
\hline
\end{tabular}

1 CID : combined immune deficiency; CHT : congenital hypoplasia of the thymus.

${ }^{2}$ Streptokinase-streptodornase, Monilia, dinitrochlorbenzene or dinitrofluorbenzene, and purified protein derivative.

Table II. Immunologically normal children with acute viral infections (infected controls)

\begin{tabular}{lcl}
\hline Patient & $\begin{array}{c}\text { Age, } \\
\text { months }\end{array}$ & \multicolumn{1}{c}{ Disease } \\
\hline$M R$ & 8 & Measles \\
$J S$ & 8 & Measles with interstitial pneumonia \\
$F S$ & 6 & Enterovirus \\
$S C$ & 16 & Laryngotracheitis, herpes simplex \\
$F G$ & 15 & Measles \\
$L G$ & 21 & Viral hepatitis \\
\hline
\end{tabular}

contained more than five dense, membrane-bound bodies per cell, and a large number of vesicles in the cytoplasm [4]. Such cells were not included in the final count.

\section{Results}

The number of cells photographed, the absolute numbers of each cell type, as well as the corresponding percentages for each patient, are shown in Table IV.

\section{Thymus Disorders}

In the children with TD, the pooled percentages of the five cell types were, respectively, 31.4, 57.1, 5.6, 5.6, and 0.3 . The counts obtained for patients with severe CID were not significantly different from those found in patients with CHT, which permitted pooling of the two results. It is possible, however, that the analysis of 
Table III. Characteristics of lymphoid cells

\begin{tabular}{|c|c|c|c|c|c|c|c|}
\hline Nomenclature & Figure & Nucleus & Cytoplasm & $\begin{array}{l}\text { Endoplasmic } \\
\text { reticulum }\end{array}$ & Polyribosomes & $\begin{array}{l}\text { Membrane-bound } \\
\text { dense bodies }\end{array}$ & $\begin{array}{l}\text { Approx. } \\
\text { size, } \mu\end{array}$ \\
\hline Small lymphocyte & $1,2,5,7$ & $\begin{array}{l}\text { Central, indented, coarse } \\
\text { chromatin pattern }\end{array}$ & Scarce & Minimal & Few or none & Few or none & $5-10$ \\
\hline $\begin{array}{l}\text { Medium lympho- } \\
\text { cyte }\end{array}$ & 2,3 & & Moderate & Occasional & Few & Occasional & $10-15$ \\
\hline Lymphoblast & 4,7 & Central, round, finely dis- & Abundant & Moderate & Prominent & None & $10-15$ \\
\hline Plasmablast & 5,7 & $\begin{array}{l}\text { persed chromatin and het- } \\
\text { erochromatin; prominent } \\
\text { nucleolus }\end{array}$ & Abundant & $\begin{array}{l}\text { Prominent, oc- } \\
\text { casionally } \\
\text { laminated }\end{array}$ & Prominent & None & - $10-15$ \\
\hline Plasma cell & 6,7 & $\begin{array}{l}\text { Eccentric round, large blocks } \\
\text { of dense chromatin in the } \\
\text { periphery }\end{array}$ & Abundant & $\begin{array}{l}\text { Prominent, } \\
\text { laminated }\end{array}$ & Occasional & None & $10-15$ \\
\hline
\end{tabular}

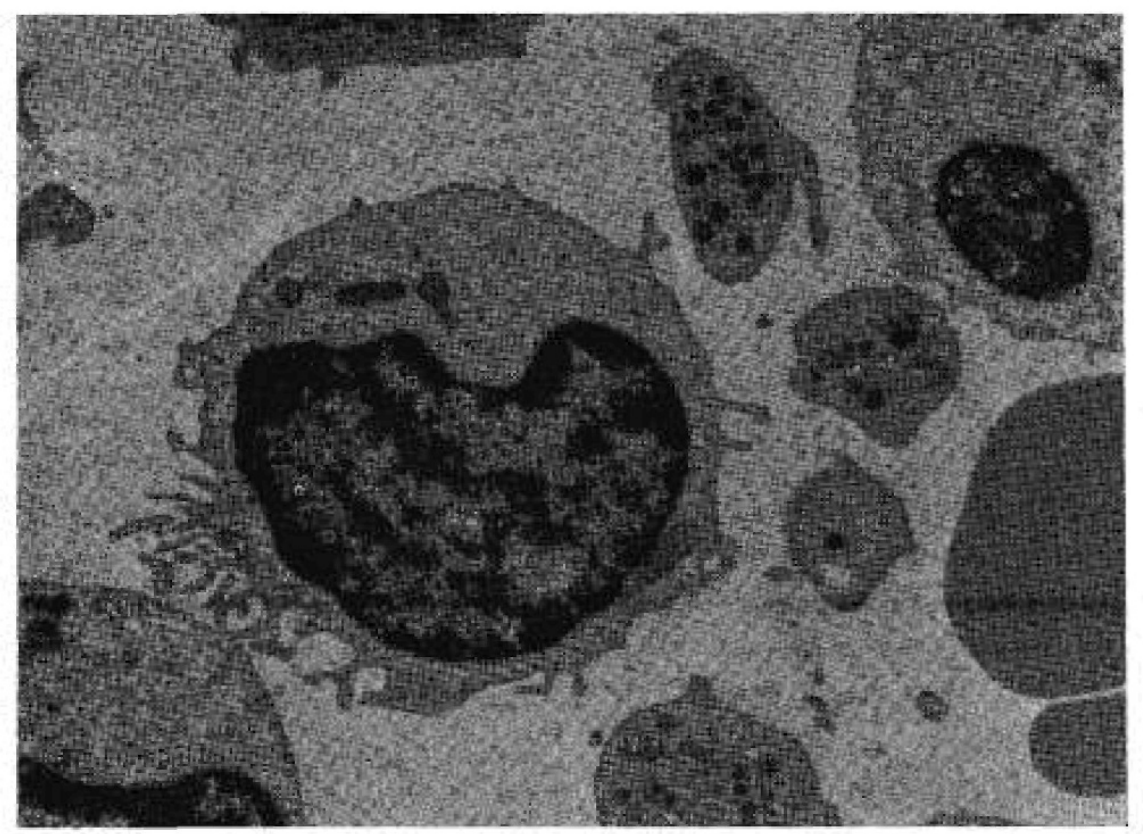

Fig. 1. Typical small lymphocytes from a normal child. The cytoplasm is scarce and contains few organelles. The nucleus is indented and contains dense clumps of chromatin, and the nucleolus is not visible. $\times 8,500$.

a large number of patients will yield significant differences between them. When average percentages of each cell type in the three groups were compared statistically, the differences were highly significant for all cell types $(P=0.002)$ (Table IV). It was considered necessary, however, to compare the absolute numbers of each cell type calculated by extrapolating the percentages observed in the electron microscope with the number of circulating lymphocytes at the time of sampling. These values are shown in Table V. The differences between total circulating lymphocytes were significant when the group with TD was compared with each control group $(P=0.01)$, whereas comparison of the two control groups yielded no significant difference. When absolute numbers of each cell type were compared in control groups, the decreased numbers of small lymphocytes in infected, as compared with normal controls, was found to be significant $(P<0.01)$. The difference in amount of medium lymphocytes was not significant, and it is evident that the presence of lymphoblasts, plasmablasts, and plasma cells in infected immunocompetent children must be considered significant, since they were not found in normal controls.

The comparison of absolute numbers of the five cell types in patients with TD and in normal controls 


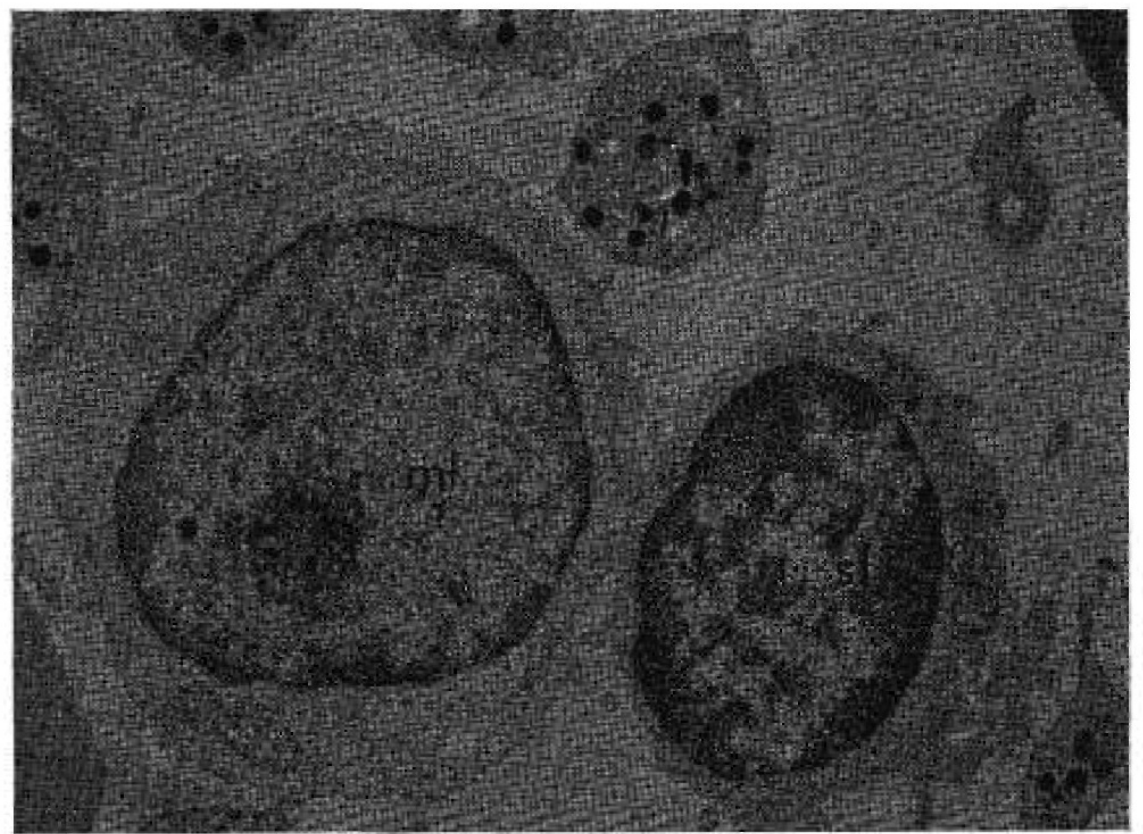

Fig. 2. Buffy-coat section from a child $(R R)$ with $\mathrm{X}$-linked severe combined immune deficiency. A small lymphocyte (sl) is shown next to a medium lymphocyte $(\mathrm{ml})$ with a large nucleus and prominent nucleolus. The cytoplasm of both cells is almost devoid of organelles. $X$ 10,000 .

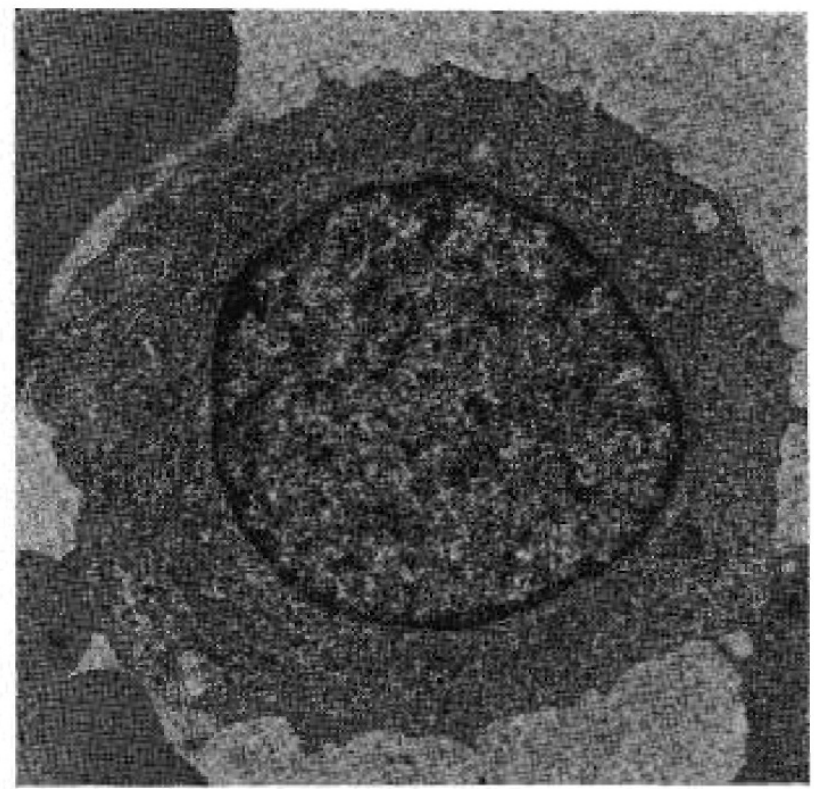

Fig. 3. Medium lymphocyte from a patient with DiGeorge's syndrome showing some polyribosome clusters and several strands of endoplasmic reticulum. $\times 10,000$.

yielded a highly significant $(P=0.001)$ decrease of small lymphocytes, and this was the main reason for lymphopenia in these patients. When absolute numbers of medium lymphocytes were compared between patients with TD and normal controls, no significant difference was noted. Finally, comparison of absolute numbers of small lymphocytes in patients with TD and in infected controls did not yield a significant difference, probably due to the wide range of values

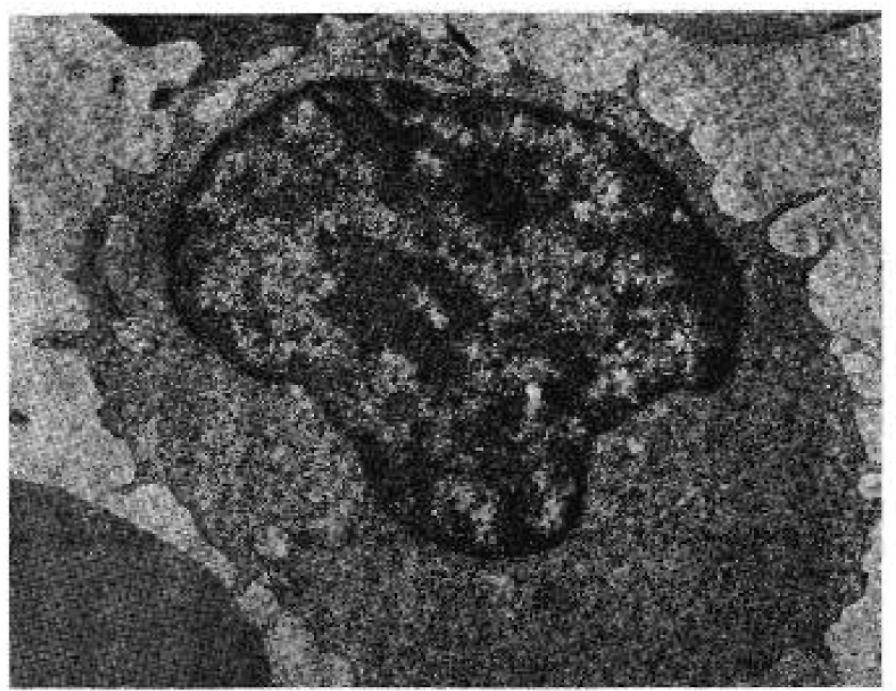

Fig. 4. Lymphoblast from an immunocompetent patient with measles. Cytoplasm contains a large number of polyribosomes. $\times 10,000$. 


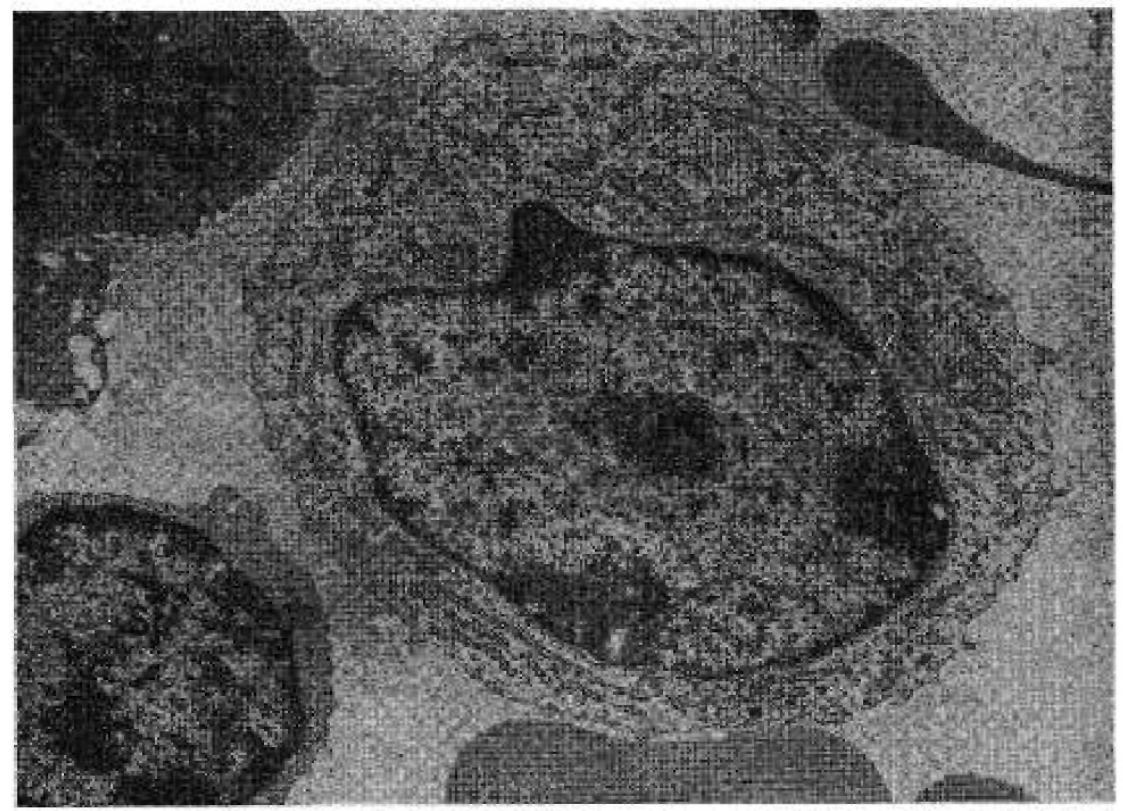

Fig. 5. Plasmablast from a patient with severe combined immune deficiency showing a large nucleus with finely dispersed chromatin and at least two nucleoli (nc). The cytoplasm contains abundant polyribosomes and some strands oc endoplasmic reticulum. A small lymphocyte (sl) may be seen in the upper and lower left corners. $\times 7,200$.

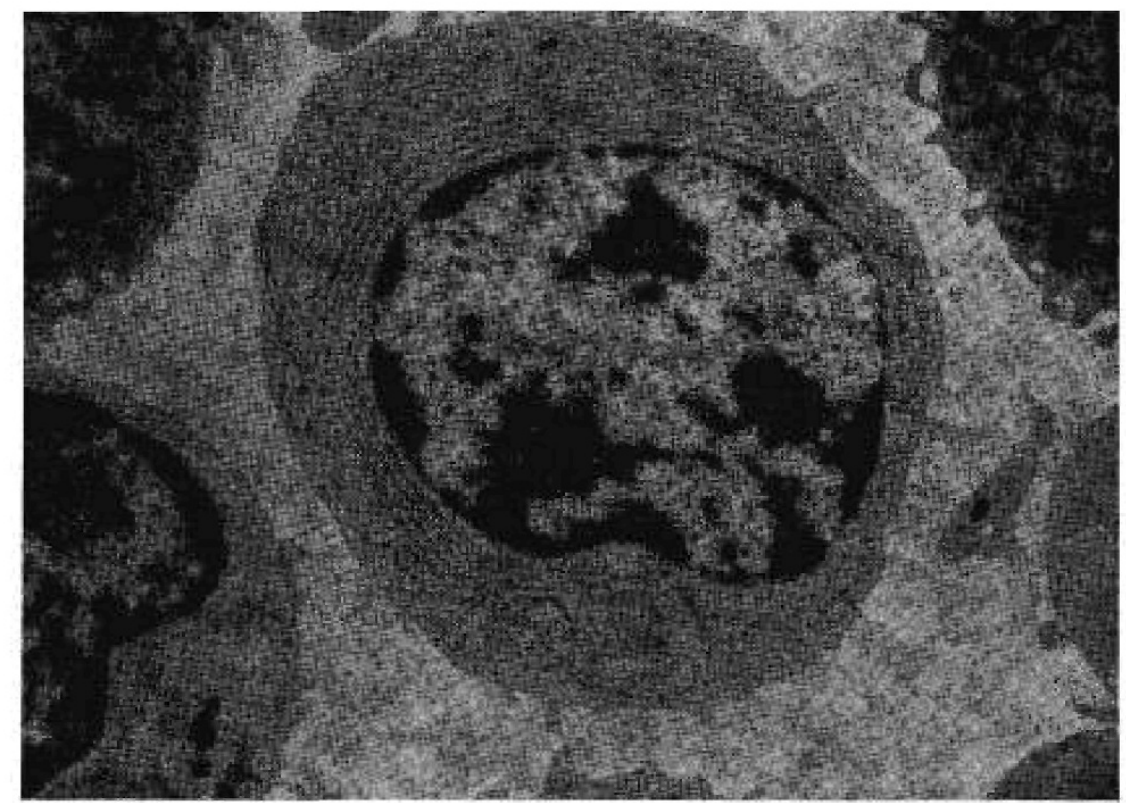

Fig. 6. Section of a typical plasma cell from an immunocompetent patient with measles. This cell type shows abundant laminated endoplasmic reticulum and very few or no polyribosome clusters. $\times 9,000$.

found in these controls (Table V). A significantly lower number of medium lymphocytes, lymphoblasts, and plasmablasts was found in patients with TD when they were compared with infected controls $(P=0.02$, 0.01 , and 0.02 , respectively). The differences in plasma cells were not significant.

\section{Control Groups}

Out of 214 classified cells in the noninfected immunocompetent children, $73.4 \%$ were small lymphocytes and $26.6 \%$ medium lymphocytes. No other cell types were found in this group. The group of infected im- 


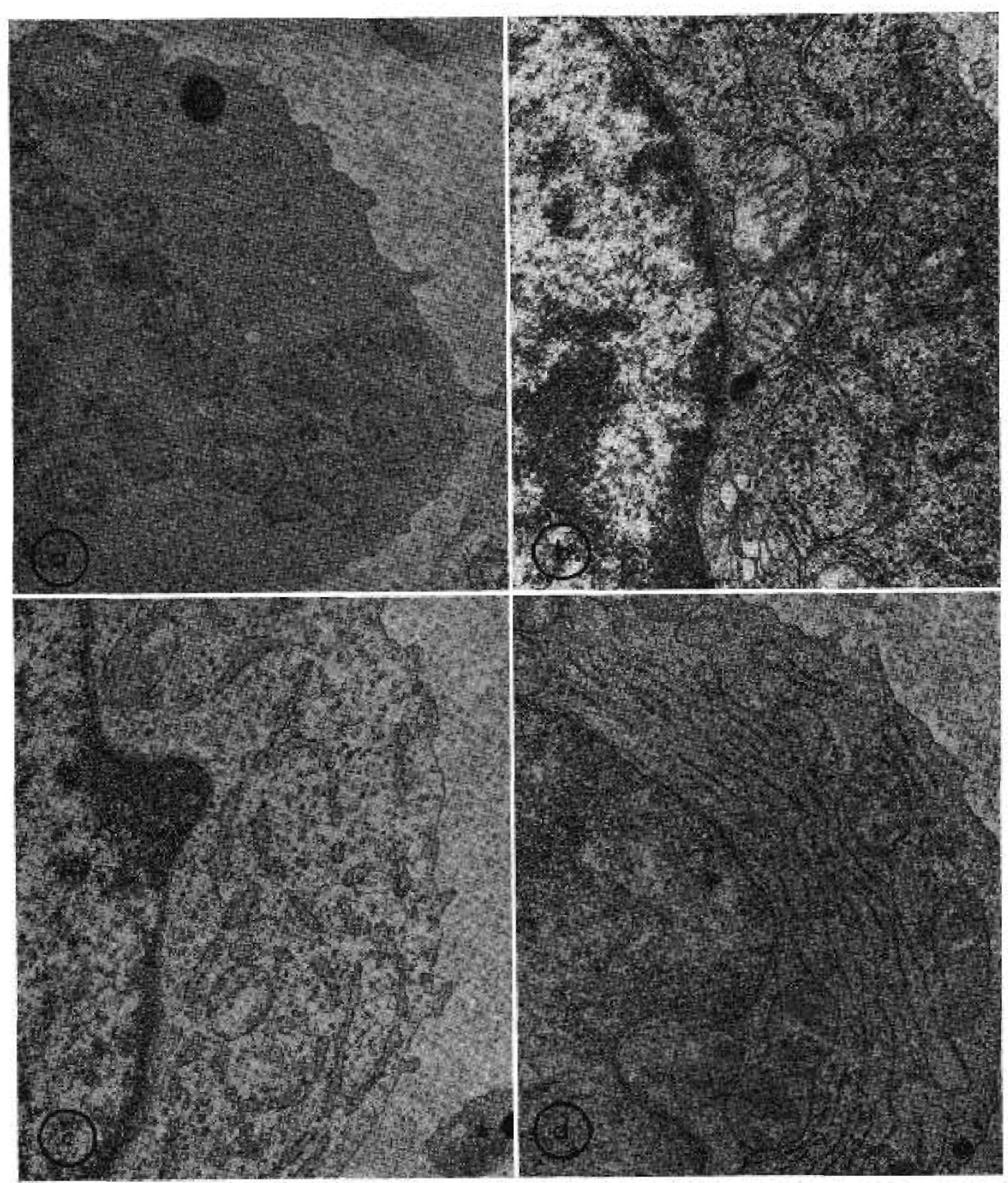

Fig. 7. Detail of lymphoid cells to illustrate differences in cytoplasmic structure. (a) Small lymphocyte with single ribosomes, a strand of endoplasmic reticulum and one dense body. $\times 17,000$. (b) Detail of a lymphoblast, with abundant polyribosomes and some strands of rough endoplasmic reticulum. $\times 17,000$. (c) Detail from plasmablast in Figure 5, illustrating large number of polyribosomes and prominent endoplasmic reticulum. $\times 17,000$. (d) Plasma cell from a patient with DiGeorge's syndrome. Cytoplasm contains abundant distended rough endoplasmic reticulum and almost no polyribosomes. $\times 20,000$.

munocompetent children exhibited the five cell types included in Table III.

\section{Discussion}

Circulating lymphocytes do not constitute a morphologically or functionally homogeneous cell population.
Functionally, two populations have been described: one, thymus-dependent, with a long half-life and fundamentally involved in cellular immunity; and another, thymus-independent population, with a short half-life and apparently not related to these phenomena $[11]$. 
Table IV. Percentage of lymphocytes in thymus disorders and control groups ${ }^{k}$

\begin{tabular}{|c|c|c|c|c|c|c|c|c|}
\hline \multirow{2}{*}{ Group ${ }^{2}$} & \multirow[b]{2}{*}{ Patient } & \multirow{2}{*}{$\begin{array}{l}\text { Blood, lympho- } \\
\text { cytes } / \mathrm{mm}^{3}\end{array}$} & \multirow{2}{*}{$\begin{array}{l}\text { Cells } \\
\text { counted }\end{array}$} & \multicolumn{5}{|c|}{ Cell type } \\
\hline & & & & $\begin{array}{c}\text { Small } \\
\text { lymphocyte }\end{array}$ & $\begin{array}{c}\text { Medium } \\
\text { lymphocyte }\end{array}$ & Lymphoblasts & Plasmablast & Plasma cell \\
\hline \multirow[t]{5}{*}{ Normal controls } & $A K$ & 4,500 & 35 & $23 / 65.7$ & $12 / 34.3$ & 0 & 0 & 0 \\
\hline & $J M$ & 5,000 & 39 & $23 / 59.0$ & $16 / 41.0$ & 0 & 0 & 0 \\
\hline & $L H$ & 5,500 & 68 & $59 / 86.8$ & $9 / 13.2$ & 0 & 0 & 0 \\
\hline & $M D$ & 6,400 & 72 & $52 / 72.2$ & $20 / 27.8$ & 0 & 0 & 0 \\
\hline & Average & 5,350 & 214 & $157 / 73.4$ & $57 / 26.6$ & 0 & 0 & 0 \\
\hline \multirow{7}{*}{ Infected (viral) controls } & $M R$ & 10,700 & 68 & $18 / 26.5$ & $14 / 20.6$ & $7 / 10.3$ & $13 / 19.1$ & $16 / 23.5$ \\
\hline & $J S$ & 8,400 & 74 & $13 / 17.6$ & $46 / 62.1$ & $14 / 18.0$ & $1 / 1.4$ & $0 / 0$ \\
\hline & $F S$ & 3,100 & 58 & $2 / 3.4$ & $31 / 53.6$ & $10 / 17.2$ & $10 / 17.2$ & $5 / 8.6$ \\
\hline & $S C$ & 8,000 & 44 & $1 / 2.3$ & $22 / 50.0$ & $9 / 20.4$ & $11 / 25.0$ & $1 / 2.3$ \\
\hline & $F G$ & 12,700 & 22 & $1 / 4.5$ & $12 / 59.1$ & $4 / 18.2$ & $4 / 18.2$ & $0 / 0$ \\
\hline & $L G$ & 6,200 & 57 & $23 / 40.4$ & $19 / 33.3$ & $4 / 7.0$ & $10 / 17.5$ & $1 / 1.8$ \\
\hline & Average & 8,200 & 323 & $58 / 18.0$ & $145 / 44.8$ & $48 / 14.9$ & $49 / 15.2$ & $23 / 7.1$ \\
\hline \multicolumn{9}{|l|}{ Thymic disorders } \\
\hline \multirow[t]{3}{*}{ СНT } & $E M$ & 1,200 & 86 & $33 / 38.4$ & $42 / 48.8$ & $2 / 2.3$ & $9 / 10.5$ & 0 \\
\hline & $C P$ & 2,500 & 85 & $26 / 30.6$ & $47 / 55.3$ & $8 / 9.4$ & $3 / 3.5$ & $1 / 1.2$ \\
\hline & Average & 1,850 & 171 & $59 / 34.5$ & $89 / 52.0$ & $10 / 6.2$ & $12 / 7.0$ & $1 / 0.6$ \\
\hline \multirow[t]{3}{*}{ CID } & $R R$ & 900 & 56 & $8 / 14.3$ & $43 / 76.8$ & $3 / 5.4$ & $2 / 3.6$ & 0 \\
\hline & $D C$ & 850 & 60 & $23 / 38.3$ & $32 / 53.3$ & $3 / 5.0$ & $2 / 3.3$ & 0 \\
\hline & Average & 875 & 116 & $31 / 26.7$ & $75 / 64.7$ & $6 / 5.2$ & $4 / 3.4$ & 0 \\
\hline CHT + CID & & 1,362 & 287 & $90 / 31.4$ & $164 / 57.1$ & $16 / 5.6$ & $16 / 5.6$ & $1 / 0.3$ \\
\hline
\end{tabular}

${ }^{1}$ All ratios expressed as absolute numbers/percent of total cells.

${ }^{2}$ CID : combined immune deficiency; CHT: congenital hypoplasia of the thymus.

Table $V$. Absolute number of lymphocytes

\begin{tabular}{llrrrrr}
\hline Group & Patient & $\begin{array}{c}\text { Small } \\
\text { sympho- } \\
\text { cyte }\end{array}$ & $\begin{array}{c}\text { Medium } \\
\text { lympho- } \\
\text { cyte }\end{array}$ & $\begin{array}{c}\text { Lympho- } \\
\text { blast }\end{array}$ & $\begin{array}{c}\text { Plasma- } \\
\text { blast }\end{array}$ & $\begin{array}{c}\text { Plasma } \\
\text { Cell }\end{array}$ \\
\hline Normal & $A K$ & 2,957 & 1,543 & 0 & 0 & 0 \\
controls & $J M$ & 2,950 & 2,050 & 0 & 0 & 0 \\
& $L H$ & 4,774 & 726 & 0 & 0 & 0 \\
& $M D$ & 4,621 & 1,779 & 0 & 0 & 0 \\
& Averages & 3,826 & 1,524 & 0 & 0 & 0 \\
Infected & $M R$ & 2,840 & 2,207 & 1,104 & 2,047 & 2,518 \\
controls & $J S$ & 1,481 & 5,226 & 1,590 & 118 & 0 \\
(virus) & $F S$ & 106 & 1,677 & 538 & 538 & 269 \\
& $S C$ & 186 & 4,033 & 1,645 & 2,016 & 185 \\
& $F G$ & 572 & 7,509 & 2,312 & 2,312 & 0 \\
& $L J$ & 2,489 & 2,051 & 431 & 1,078 & 111 \\
& Averages & 1,279 & 3,784 & 1,270 & 1,352 & 514 \\
CHT & $E M$ & 460 & 586 & 28 & 126 & 0 \\
& $C P$ & 765 & 1,383 & 235 & 88 & 30 \\
& Averages & 613 & 984 & 131 & 107 & 15 \\
CID & $R R$ & 128 & 691 & 49 & 33 & 0 \\
& $D C$ & 325 & 453 & 43 & 28 & 0 \\
\multirow{5}{*}{ Pool TD } & Averages & 227 & 572 & 46 & 30 & 0 \\
& & 420 & 778 & 88 & 69 & 8 \\
\hline
\end{tabular}

${ }^{1}$ CHT: congenital hypoplasia of the thymus; CID : combined immune deficiency; TD : thymus disorders.

Several physiological differences have been described for these two cell populations; thus, thymus-dependent lymphocytes, as estimated by their ability to respond to PHA in vitro, are more labile to hypotonic shock
[25]. Antilymphocyte serum also selectively affects the thymus-dependent lymphoid population [3]. The two populations also differ in their cytoelectrophoretic mobility [24], adherence to plastic surfaces [21], and organ distribution ("homing") upon injection in syngeneic recipients [9]. Unfortunately, it has been impossible so far to identify these two populations with a typical morphology $[1,3,13,17,20]$.

In the present study, all cell types found in the blood of infected immunocompetent children were also found in the blood of patients with TD, and only the relative proportion of the cell types varied significantly. Thus, it was found that lymphopenia of TD was largely due to a decrease in the number of small lymphocytes. Although the percentage of medium lymphocytes was predominant in TD, their absolute numbers were not significantly different when compared with those found in normal controls, and were even significantly decreased when compared with those of infected controls. This may reflect arrested lymphoand/or blastogenesis in these patients since the medium lymphocyte does not seem to be an "end-cell" [26]. Large lymphoblasts and plasma cells were not found in the circulation of normal children, but were found in the blood of immunocompetent infected controls, as well as in patients with TD. Such cells have also been described in the course of viral infections, 
collagen diseases, and in certain tumors [5], and they are thought to derive either from small lymphocyte blastogenic transformation to premitotic cells or as intermediate cells in the process of lymphogenesis [16]. The presence of these cells in TD suggests the existence of at least some degree of lympho- and/or blastogenic activity.

If they derive from blastogenic activity, then the chronic, predominantly viral infections these patients are known to sustain [12] may constitute the stimulus for this activity, notwithstanding the fact that viruses are considered poor blastogenic agents in vitro [19]. The fact that in vitro responses to PHA and antigenic stimulation are not altogether absent in lymphocytes from patients with TD seems to be in accordance with this. During the present study, only one child had a positive viral culture (adenovirus) prior to sampling, but all four showed unequivocal signs and symptoms of chronic infection.

Furthermore, it has been suggested that small lymphocytes are capable of responding to certain stimuli with an incomplete or "sterile" transformation which does not render them capable of immunological function [18]. The observation that patients with TD revealed lymphoid cell types compatible with blastogenic transformation, but lack the ultimate immunological functions associated with them, may be alternately explained in this context.

Finally, one has to be cautious in extrapolating purely morphological observations to functional aspects. It seems, though, that circulating lymphocytes in "TD are undergoing some sort of reactive activity as judged by the presence of lymphoblasts, plasmablasts, and even plasma cells. Further studies are necessary to clarify these reactive potentialities.

The immunological defect in one patient, $E M$, was corrected by a thymic implant. Ultrastructural studies of his lymphocytes following this procedure revealed a distribution of cell types which was entirely normal.

\section{Summary}

Ultrastructural studies of peripheral blood lymphoid cells from infants with congenital hypoplasia of the thymus and severe combined immune deficiency disease revealed the presence of normal numbers of medium lymphocytes and the presence of immature forms (lymphoblasts, plasmablasts, and plasma cells). Such immature forms were not found in the blood of normal children but are present in age-matched controls with viral infections. Infants with congenital thymic disorders were found to have an absolute deficit in the number of small lymphocytes. Although the blood of the infected controls contained a preponderance of medium lymphocytes, there was no significant concomitant deficit in small lymphocytes.

The immunological defect in one infant with congenital hypoplasia of the thymus was corrected by an implant of fetal thymus. Subsequently, the distribution of lymphoid cells in his peripheral blood was the same as that observed in the normal controls.

\section{References and Notes}

1. Anderson, D. R.: Ultrastructure of normal and leukemic leucocytes in human peripheral blood. J. Ultrastruct. Res., Suppl. 9: 1 (1966).

2. Benacerraf, B., AND Green, I.: Cellular hypersensitivity. Annu. Rev. Med., 20: 141 (1969).

3. Brent, L., Courtenay, T., and Gowland, G.: Anti-lymphocytic serum: Its effect on the reactivity of Iymphocytes. In: J. Dausset, G. Hamburger, and G. Mathe: Proc. First Int. Congr. Transplant. Soc. (Paris), p. 117 (Munksgaard, Copenhagen, 1968).

4. Corn, Z. A.: The structure and function of monocytes and macrophages. Advan. Immunol., 9: 163 (1969).

5. Growther, D., Fairley, G. H., and Sewell, R. L.: Significance of the changes in the circulating lymphoid cells in Hodgkin's disease. Brit. Med. J., 2: 473 (1969).

6. Digeorge, A. M., Lischner, H. W., Dacov, C., And Arey, J. B.: Absence of the thymus. Lancet, $i: 1387$ (1967).

7. Glanzmann, E., And Riniker, P.: Essentielle Lymphocytophthise. Ein Krankheitsbild aus der Sauglingspathologie. Ann. Paediat., 175: 1 (1950)

8. Gowans, J. L.: The immunological activities of lymphocytes. Progr. Allergy, 9: 1 (1965).

9. Griscelly, C., Vassalxi, P., and McCluskey, R. T.: The distribution of large dividing lymph node cells in syngeneic recipient rats after intravenous injection. J. Exp. Med., 130: $1427(1969)$.

10. Hixzrg, W. H., Biro, Z., Bosch, H., AND Huser, H. J.: Agammaglobulinämie und Alymphocytose mit Schwund des lymphatischen Gewebes. Helv. Paediat. Acta, 13: 551 (1958).

11. Holborow, E. J.: The immunological capability of small lymphocytes. Lancet, $i$ : 1049 (1967).

12. Hoyer, J. R., Cooper, M. D., Gabrielsen, A. E., and Good, R. A.: Lymphopenic forms of congenital immunological deficiency. Medicine, 47: 201 (1968).

13. Hummeler, K., Harris, T. N., Tomassint, N., Hechtel, M. AND FARBER, M. B.: Electron microscopy of antibody-producing cells in lymph and blood. J. Exp. Med., 124: 255 (1966).

14. Kretschmer, R. R., JeAnnet, M., Mereu, T. R., Kretschmer, K., WINN, H., AND Rosen, F. S.: Hereditary thymic dysplasia: A graft-versus-host reaction induced by bone marrow cells with a partial 4 a series histoincompatibility. Pediat. Res., 3: 34 (1969).

15. Kretschmer, R. R., SAy, B., Brown, D., and Rosen, F. S.: Congenital aplasia of the thymus. New Engl. J. Med., 279: 1295 (1968).

16. La Vra, M. F., Vatter, A. E., Claman, H. N., and BrunstetTER, F. H.: Effects of antilymphocyte serum and phytohemag- 
glutinin upon cultures of human thymus and peripheral blood lymphoid cells. II. Electron microscopic studies of thymus cells. Lab. Invest., 18: 763 (1968).

17. Lennert, K., Caesar, R., AND MUller, H. K.: Electron microscopic studies of germinal centers in man. In: $E$. Cottier, N. Odarcheko, R. Schindler, and C. C. Congdon: Germinal Centers in Immune Responses (Springer-Verlag, New York, 1967).

18. Levey, R. H., AND Medawar, P. B.: Further experiments on the action of antilymphocytic antiserum. Proc. Nat. Acad. Sci. U. S. A., 58: 470 (1967).

19. LiNG, N. R.: Lymphocyte Stimulation, p. 258 (Wiley \& Sons, New York, 1968).

20. Mori, Y., AND LenNert, K.: Electron Microscopic Atlas of Lymph Node Cytology and Pathology. (Springer-Verlag, Berlin, Heidelberg, New York, 1969).

21. Mosier, D. E.: A requirement for two cell types for antibody formation in vitro. Science, 158: 1573 (1967).

22. Parror, D. M. V., DeSousa, M. A. B., AND EAST, J.: Thymusdependent areas in the lymphoid organs of neonatally thymectomized mice. J. Exp. Med., 123: 191 (1966).

23. Rosen, F. S., Gitlin, D., ANd Janeway, C. A.: Alymphocytosis, agammaglobulinemia homografts and delayed hypersensitiv. ity. Study of a case. Lancet, ii: 380 (1962).

24. Ruhenstroth-Bauer, G., and Lucke-Huhla, C.: Two populations of small lymphocytes. J. Cell. Biol., 37: 196 (1968).

25. Thomson, A. E. R., Bull, J. M., and Robinson, M. A.: A procedure for separating viable lymphocytes from human blood and some studies on their susceptibility to hypotonic shocks. Brit. J. Haematol., 12: 433 (1966).

26. Yoffey, J. M.: The Lymphocyte in Immunology and Haemopoiesis. (E. Axnold, London, 1967).

27. ZuGKer-Franklin, D.: The ultrastructure of cells in human thoracic duct lymph. J. Ultrastruct. Res., 9: 325 (1963).

28. Phillips EM 200 and EM 300, Phillips Electronic, Mount Vernon, N: Y.

29. Supported by Public Health Service Research Grants nos. AI-05877 and FR-00128.

30. Dr. Rosen is the recipient of Public Health Service Research Career Development Award no. 1-K3-AM-19, 650.

31. Request for reprints should be addressed to: F. S. Rosen, M.D., The Children's Hospital, 300 Longwood Avenue, Boston, Mass. 02115 (USA).

32. Accepted for publication September 16, 1970. 